\title{
SATELLITE-DERIVED GRAVIMETRY FOR ABROLHOS CONTINENTAL SHELF, STATES OF ESPÍRITO SANTO AND BAHIA, BRAZIL, AND ITS RELATION TO TECTONIC GENESIS OF SEDIMENTARY BASINS
}

\author{
Akihisa Motoki ${ }^{1}$, Luiz Carlos Chaves Novais², Kenji Freire Motoki ${ }^{3}$, Leonardo Costa de Oliveira4 ${ }^{4}$, \\ Ricardo de Souza Fasolo $0^{5}$ and Adrienne Brito Lima ${ }^{5}$
}

\begin{abstract}
This paper presents the results of satellite-derived gravimetry for Abrolhos Continental Shelf and the adjacent areas, States of Espírito Santo and Bahia, Brazil, and discusses tectonic genesis of the sedimentary basins. The free-air and Bouguer anomalies on the continental shelf show a gradual increase from coast to continental shelf break. The total difference of $135 \mathrm{mGal}$ indicates crust thinning of $4.5 \mathrm{~km}$. The Bouguer anomaly increases beyond the shelf break and continues up to the abyssal plane. The total difference of $260 \mathrm{mGal}$ suggests crustal thinning of $9.0 \mathrm{~km}$. The studied area has two types of passive continental margin: 1) ES-type with high continental slope, low and narrow continental rise, and high free-air and Bouguer anomalies; 2) SP-type with low continental slope, high and wide continental rise, and low gravity anomalies. There are three types of sedimentary basins with different geologic structure and tectonic genesis: 1) Basins on the continental shelf, CSH-type; 2) Basin on the continental rise, CRS-type; 3) Continental rift basin, CRF-type. The CSH-type, as Espirito Santo basin, has coherent free-air and Bouguer anomalies 40 to $50 \mathrm{mGal}$ lower than the adjacent areas. The sedimentary deposits are 2.0 to $2.5 \mathrm{~km}$ thick. The basement depression is sustained by mechanical strength without isostatic compensation. The normal faults of basin border are limited within upper crust. The CRS-type, as Pedro Canário basin, has low local residual Bouguer anomaly with difference of $40 \mathrm{mGal}$. The sedimentary deposits are more than $2.7 \mathrm{~km}$ thick. The continental side basin border is under isostatic compensation due to deep normal fault between continental slope and continental rise. The oceanic side border is sustained by mechanical strength of the basement. The CRF-type, Besnard Passage, is a continental rift basin originated from mantle pull-apart tectonism. The rift bottom is under complete isostatic compensation. The normal faults of the graben border continue to the mantle. The Moho depth along the rift is at least $6.5 \mathrm{~km}$ shallower than the adjacent areas.
\end{abstract}

Keywords: satellite-derived gravimetry, Abrolhos Continental Shelf, sedimentary basin, crustal thinning, isostatic compensation.

RESUMO. Este artigo apresenta os resultados da gravimetria por satélite para a Plataforma Continental de Abrolhos e as áreas adjacentes, ES-BA, e discute as gêneses tectônicas das bacias sedimentares. As anomalias ar-livre e Bouguer na plataforma continental mostram um aumento gradativo a partir da costa até a quebra da plataforma continental. A diferença total de $135 \mathrm{mGal}$ indica afinamento da crosta continental de 4,5 km. A anomalia Bouguer se apresenta além da quebra da plataforma e continua até 0 assoalho abissal. A diferença total de $260 \mathrm{mGal}$ sugere afinamento crustal de $9,0 \mathrm{~km}$. Na área estudada, observam-se dois tipos de margem continental passiva: 1) Tipo ES com talude continental alto, elevação continental baixa e curta e anomalias ar-livre e Bouguer altos; 2) Tipo SP com talude continental baixo, elevação continental alta e extensa e anomalias gravimétricas baixas. Existem três tipos de bacias sedimentares com estrutura geológica e gênesis tectônicas diferentes: 1) Bacias na plataforma continental, Tipo CSH; 2) Bacias na elevação continental, Tipo CRS; 3) Bacia de rifte continental, Tipo CRF. 0 Tipo CSH, como a bacia do Espírito Santo, possui anomalias ar-livre e Bouguer coerentes 40 a 50 mGal mais baixas do que as áreas adjacentes. Os depósitos sedimentares são de 2,0 a 2,5 km de espessura. A depressão do embasamento é sustentada pela rigidez mecânica sem compensação isostática. As falhas normais das bordas de bacias são limitadas dentro da crosta superior. 0 Tipo CRS, como a bacia Pedro Canário, tem baixa anomalia Bouguer local com diferença de $40 \mathrm{mGal}$. Os depósitos sedimentares têm mais de 2,7 km de espessura. A borda da bacia do lado continental está sob compensação isostática devido à falha normal profunda entre talude continental e elevação continental. A borda do lado oceânico é sustentada pela rigidez mecânica do embasamento. 0 Tipo CRF, Passagem Besnard, é uma bacia do rifte continental originada do tectonismo de distensão do manto. 0 fundo da bacia está sob compensação isostática completa. As falhas normais da borda do graben continuam até o manto. A profundidade da Moho ao longo do rifte é pelo menos 6,5 km mais rasa do que as áreas adjacentes.

Palavras-chave: gravimetria por satélite, Plataforma Continental de Abrolhos, bacia sedimentar, afinamento crustal, compensação isostática.

1 Universidade do Estado do Rio de Janeiro, Department of Mineralogy and Petrology, Rio de Janeiro, RJ, Brazil.

2 Petrobras, Operation Unit of Espírito Santo, Edifício Madison Office Tower, Rua Darcy Grijó, 50, térreo, loja 11, Jardim da Penha, 29060-500 Vitória, ES, Brazil. Phone-Fax: +55(27) 3295-5377 - E-mail: novais@petrobras.com.br

3 Universidade Federal Fluminense, Department of Geology, Rua Marques de Caxias, 225, Casa 2, Centro, 20550-990 Niterói, RJ, Brazil. Phone: +55(21) 2613-3189 - E-mail: kenji_d@@hotmail.com

${ }^{4}$ Petrobras, Rio de Janeiro Head Quarter, Av. República do Chile, 330, Edifício Ventura, $26^{\circ}$ andar, Torre Oeste, Centro, 20031-170 Rio de Janeiro, RJ, Brazil. Phone: +55(21) 2167-5703 - E-mail: leogeo.oliveira@petrobras.com.br

${ }^{5}$ Universidade Federal do Espírito Santo, São Mateus Campus, Rodovia BR-101, Norte Km 60, 29932-540 São Mateus, ES, Brazil. Phone: +55(27) 3312-1511

- E-mails: fazollodh@gmail.com; adrienne.lima30@gmail.com 


\section{INTRODUCTION}

Gravimetric exploration is an efficient geophysical instrument for the study of geologic structures of the crustal. Ship-borne gravimetry provides high precision primary data but it is inconvenient to cover a very large area as whole South Atlantic Ocean. A breakthrough is topographic and gravimetry mapping based on orbital perturbation analyses of artificial satellites.

The experimental study of satellite-derived gravimetry started from the first artificial satellite Sputnik 1 in 1957 (Kaula, 1987). This technique has been improved and applied not only to the Earth, but also to other planets and satellite (e.g. Muller \& Sjogren, 1968; Lorell, 1970; Lambeck \& Coleman, 1983). The combination with radar altimetry enables high-precision orbit analyses and the consequent high-resolution mapping (e.g. Zuber et al., 1994; Rummel, 2005; Goossens et al., 2011). The satellite-borne gravimetric data of long period of distance are useful for geoid surface determination (e.g. Douglas \& Goad, 1978; Reigber et al., 2002; Reubelt et al., 2003).

In the oceanic regions, sea water lamina thickness is an important factor for satellite-derived free-air anomaly, and therefore, ocean depth can be estimated from the gravity data (Fig. 1, dashed line). The estimated depths are generally little different from the ship-borne data of direct bathymetry due mainly to local heterogeneity of crust and mantle structure. Adopting the ship-borne data as bathymetric benchmarks, the submarine morphology of the areas off the ship-borne trajectories can be reconstituted from the gravimetric data with the help of adequate calibration and correction. The correction values (Fig. 1, striped area) have information of Bouguer anomaly.

Based on the above-mentioned principle with some additional assumptions Smith \& Sandwell (1997) released a world wide bathymetric map. The method continues in improvement by the consecutive accumulation of satellite and ship-borne data and new technical innovations, developing the correction procedures of geoid effect and gravitational vertical off-set (e.g. Sandwell \& Smith, 2009). They brought a notable evolution of data resolution and accuracy (Fig. 2).

At the present, there are many databanks of satellite-derived bathymetry, as IBCAO, GINA, J-EGG, JODC, RIDGE, ETOPO2, ETOP01, ETOP030, GEBC0, and TOPEX. Among them, the bathymetric data of GEBCO and TOPEX are preferred by the authors of scientific research papers. The data of GEBCO (General Bathymetric Chart of the Oceans) are distributed from IHO (International Hydrographic Organization). During the 20th century, world-wide bathymetric map of GEBCO had been based on shipborne data, but since 2002, IHO has adopted satellite-derived data as the main instrument. Apparent resolution of the topographic map is $0.925 \mathrm{~km}$.

The data of TOPEX are distributed from Scripps Institution of Oceanography, University of California, San Diego (UCSDSIO). This institution provides either topographic or free-air data, called respectively TOPEX and Gravity Anomaly. Bouguer anomaly is calculated from these data. Apparent resolution of the topographic data is $0.925 \mathrm{~km}$ and that of free-air data is $1.85 \mathrm{~km}$.

The United States National Geospatial-Intelligence Agency (NGA) provides free-air, Bouguer, and isostatic anomaly maps, called EGM2008. The databank were constructed according to the international cooperation project with France, called Bureau Gravimétrique International. Apparent resolution of the free-air map is $4.63 \mathrm{~km}$ and that of other maps are lower.

The satellite-derived topographic and gravimetric data are useful for structural studies of large-scale oceanic regions. In Brazil, they have been applied to the geotectonic studies of mantle exhumation tectonic process of Equatorial Atlantic Ocean (Sichel et al., 2011; Motoki et al., 2014). The method is efficient also to continental passive margin, with special attention of sedimentary basins and continental crust thinning (Motoki \& Motoki, 2012).

The authors have preformed gravimetric and geomorphologic studies for Abrolhos Continental Shelf, States of Espírito Santo and Bahia, Brazil, based on the data of TOPEX version 14.1 and Gravity Anomaly version 18. The gravimetric data of EGM2008 also are adopted as an auxiliary reference. This article presents the results and discusses two types of continental margins and three types of sedimentary basins with different structure and tectonic origins, which were formed during the crustal thinning stage of the Atlantic Ocean opening.

\section{RESEARCH METHODS}

The satellite-derived bathymetric data of TOPEX and the free-air gravimetric data of Gravity Anomaly cover all of the oceanic areas of the world between $72^{\circ} \mathrm{N}$ and $72^{\circ} \mathrm{S}$. Their first version had apparent horizontal resolution of $3.7 \mathrm{~km}$, which corresponds to 2 minute of latitude. However, its real resolution was lower, estimated to be 10 to $20 \mathrm{~km}$.

According to the accumulation of satellite and ship-borne data, the satellite-derived data quality was improved remarkably either in resolution or in precision, especially after 2005 . The TOPEX version 14.1 and Gravity Anomaly version 18 were released on July 22, 2011 and have apparent resolution of $1.85 \mathrm{~km}$, that is, 1 minute of latitude. For the topography, the data with $0.925 \mathrm{~km}$ of apparent resolution is available, which corresponds to $30^{\prime \prime}$. 


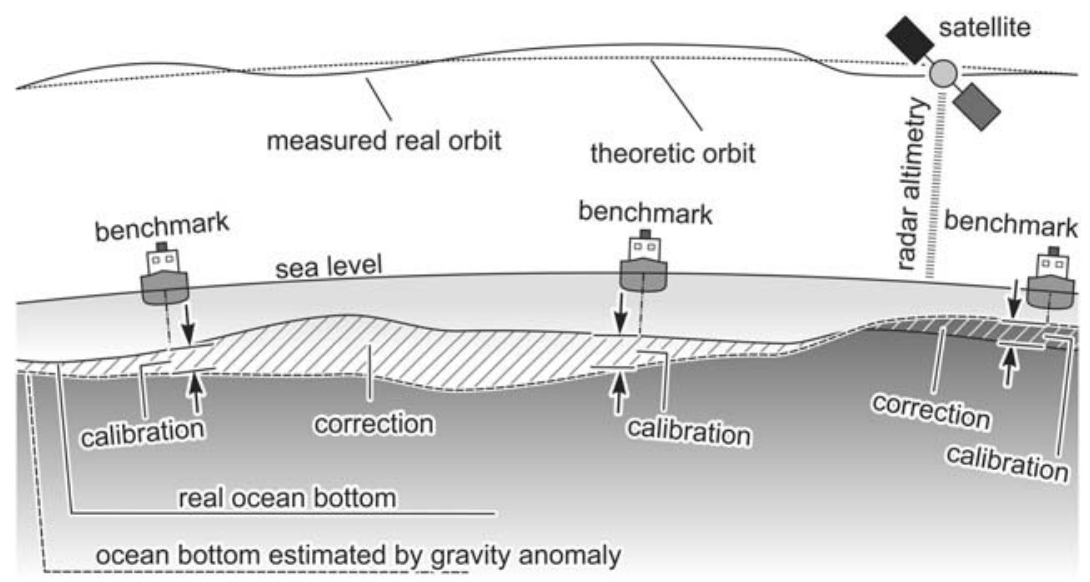

Figure 1 - Principle of satellite-derived bathymetry by orbit perturbation analyses, called predicted bathymetry, using ship-borne bathymetric data as the benchmarks for calibration.

\section{A. GEBCO 1997}

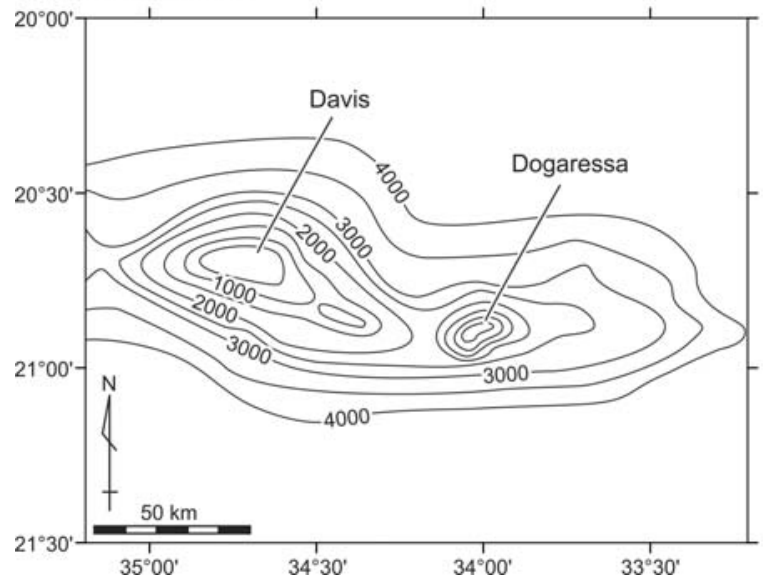

B. TOPEX 14.1, 2011

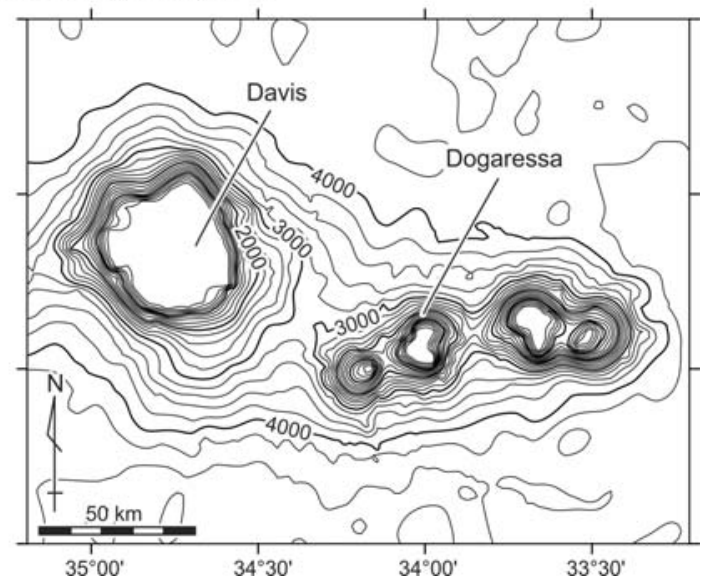

Figure 2 - Resolution comparison of the bathymetric maps for the central part of Vitória-Trindade Seamount chain, offshore of State of Espírito Santo, Brazil (Motoki et al., 2012): A) Digital Atlas of GEBC0 1997 based on ship-borne bathymetry; B) Satellite-derived bathymetry of TOPEX version 14.1 released in 2011.

Along the benchmarks of ship-borne trajectories, the apparent resolutions are real, that is, $0.925 \mathrm{~km}$. The comparison between topographic and free-air data suggests that the real resolution for the areas off the benchmark trajectories is about $4.6 \mathrm{~km}$. The predicted depth of guyots indicates that the vertical resolution is about $50 \mathrm{~m}$. TOPEX dataset is widely used for scientific documents, including Brazilian ones (e.g. Sichel et al., 2008; 2011; Motoki et al., 2009; Campos et al., 2010).

The Gravity Anomaly version 18 and EGM2008 have respective apparent horizontal resolution of 1.85 and $4.63 \mathrm{~km}$. The real resolution of Gravity Anomaly version 18 also is higher than that of EGM2008. The free-air data of the both databanks sometimes show controversy in determined areas. This problem is still open and their correlation and validation are required.

For the calculation of simple Bouguer anomaly, the authors developed original software SCHWELT version 1.0. Continen- tal crust density is estimated to be $2.65 \mathrm{~g} / \mathrm{cm}^{3}$, sea water density as $1.03 \mathrm{~g} / \mathrm{cm}^{3}$, and gravitational constant as $6.67259 \times$ $10^{-11} \mathrm{~m}^{3} / \mathrm{s}^{2} \mathrm{~kg}$.

The real resolution of the topographic data is higher than that of free-air data. In addition, TOPEX contains few data noises. These factors cause acute false peaks on the topographic map and false depressions on the Bouguer anomaly map. The problems can be mitigated by adequate manual operations. The original softwares for the solution of this problem are in development.

\section{REGIONAL GEOLOGY}

The studied area is located in the offshore of States of Espirito Santo and Bahia, Brazil, between latitude $17^{\circ} \mathrm{S}$ to $20^{\circ} \mathrm{S}$, which covers Abrolhos Continental Shelf and the adjacent continental slope and continental rise (Fig. 3). Because of the sedimentary 


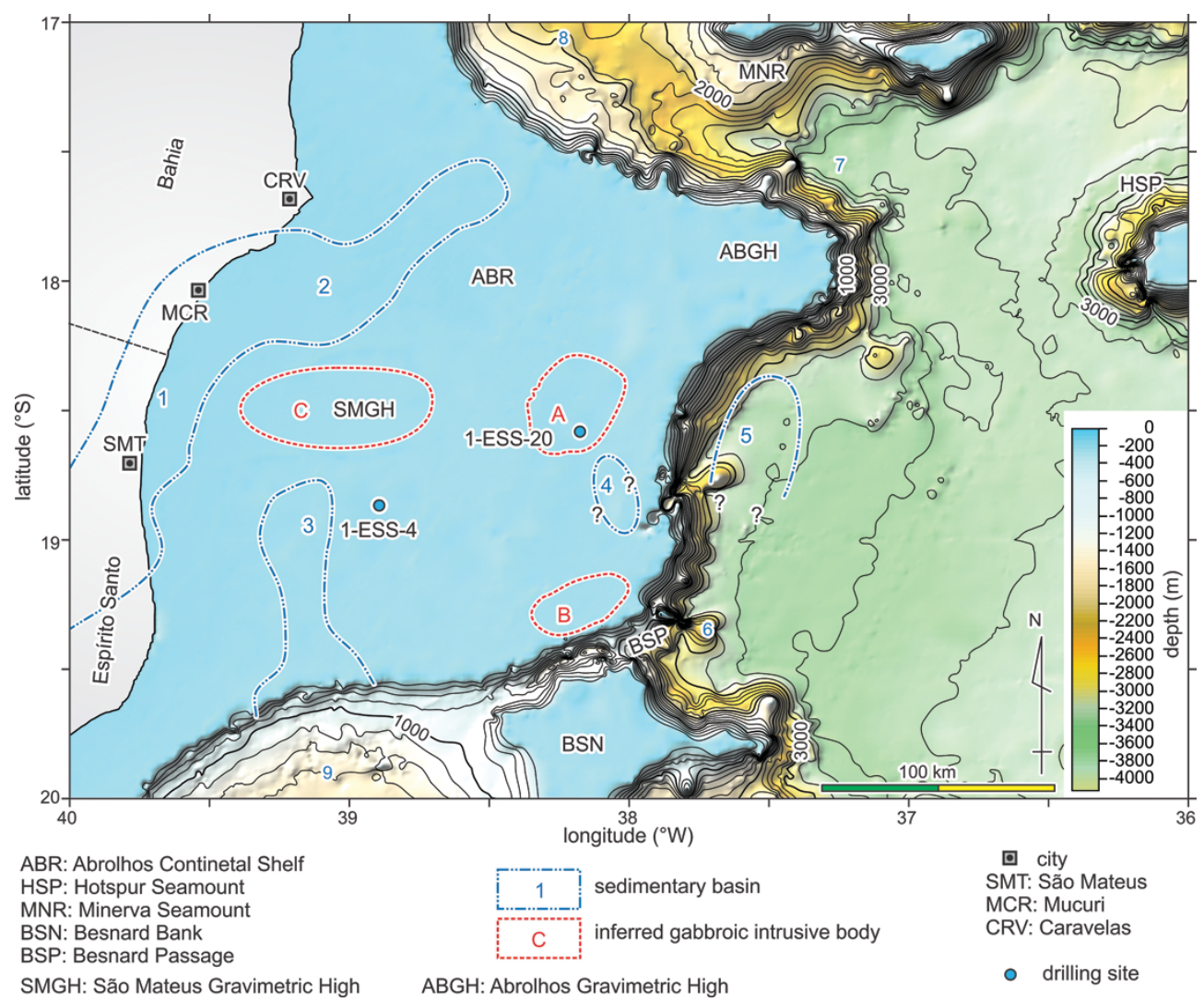

Figure 3 - Resolution comparison of the bathymetric maps for the central part of Vitória-Trindade Seamount chain, offshore of State of Espírito Santo, Brazil (Motoki et al., 2012): A) Digital Atlas of GEBC0 1997 based on ship-borne bathymetry; B) Satellite-derived bathymetry of TOPEX version 14.1 released in 2011.

basins with hydrocarbon deposits, intense seismic, magnetic, and gravimetric explorations and tow deep drillings have been preformed by Petrobras (e.g. Sobreira \& França, 2005). In the present paper, the term sedimentary basin, such as Espírito Santo basin, is used exclusively in geologic sense, that is, basement depression with accumulation of sedimentary deposits, and not of mining administration sense, which corresponds to the oil exploitation division areas in Brazilian continental margin.

Espírito Santo sedimentary basin (França et al., 2007a; Fig. 3, Basin 1) has NNE-SSW direction, which is $120 \mathrm{~km}$ long and $40 \mathrm{~km}$ wide. Mucuri basin (França et al., 2007b; Fig. 3, Basin 2) has NE-SW direction, $100 \mathrm{~km}$ long and $30 \mathrm{~km}$ wide. About $80 \mathrm{~km}$ to east of city of São Mateus, there is another sedimentary basin of $\mathrm{N}-\mathrm{S}$ direction with $70 \times 30 \mathrm{~km}$ of extension on the continental shelf (Sobreira \& França, 2005; Fig. 3, Basin 3). In this paper, it is called São Mateus basin. These basins are characterised by salt domes.

Close to the continental shelf break, salt dome structures are found in an area of $20 \times 40 \mathrm{~km}$ (Sobreira \& França, 2005; Fig. 3, Area 4). The seismic section for this area shows sub-horizontal sedimentary layers covering the continental shelf without base- ment depression (Gladczenko et al., 1997). In this sense, this area is not considered to be a sedimentary basin of geologic sense.

The margin of Espírito Santo and Mucuri sedimentary basins are delimited by N-S to NNE-SSW ward faults, called Cedro-Rio Doce system (Vieira, 1998), and of NNW-SSE to NW-SE ward faults, named Colatina system (Novais et al., 2003, 2006). The fractures of Cedro-Rio Doce system are main conductor of hydrocarbon migration (Motoki et al., 2007; Novais et al., 2007).

The drilling hole 1-ESS-4 detected volcanic rock layers with total thickness of $1700 \mathrm{~m}$ constituted by basalt and pyroclastic rocks. The drilling hole 1-ESS-20 also obtained sedimentary and pyroclastic rocks. Sobreira \& França (2005) suggested possible existence of three large gabbroic intrusive bodies. Two of them, called plutons $A$ and B (Fig. 3), situated respectively at $180 \mathrm{~km}$ to east and $200 \mathrm{~km}$ to ESE of city of São Mateus, show clear magnetometric anomaly without gravimetric anomaly. These characteristics are common in mafic intrusive bodies, such as wide dykes and thick sills. There is a gravimetric high zone at $80 \mathrm{~km}$ to ENE of São Mateus, called São Mateus gravimetric high (SMGH). These authors proposed a large gabbroic intrusion called pluton $\mathrm{C}$ in spite of the absence of magnetometric anomaly. 

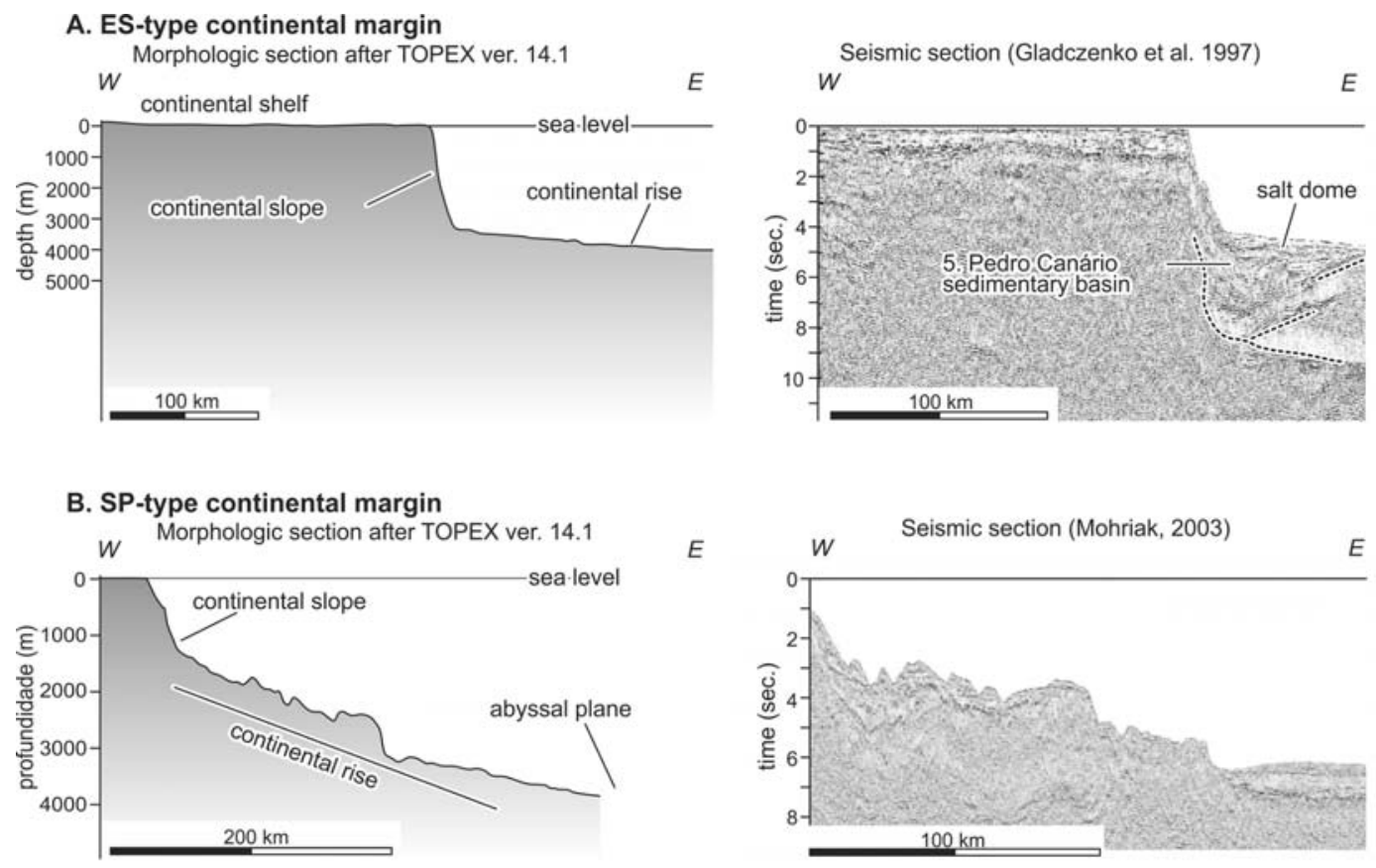

Figure 4 - Bathymetric and seismic sections of two contrasted types of passive continental margin modified from Motoki et al. (2012): A) ES-type (Espírito Santo type) of Abrolhos Continental Shelf along latitude 18³0'S; B) SP-type (São Paulo type) of Guarapari offshore, along 2115'S.

The seismic and geologic sections obtained by Petrobras in the continental area around São Mateus indicate the uplift of western border of Espírito Santo sedimentary basin (Sobreira \& França, 2005) in which basal sedimentary layers are exposed. The fission track datings for apatite point out two uplift events, from 90 to $80 \mathrm{Ma}$ and from 70 to $60 \mathrm{Ma}$ (e.g. Remus et al., 2008).

\section{TWO TYPES OF CONTINENTAL MARGIN}

Abrolhos Continental Shelf has an extension of $240 \times 240 \mathrm{~km}$ with a total area of $60000 \mathrm{~km}^{2}$. Its surface is very flat and the sedimentary basins and gabbroic intrusions (Sobreira \& França, 2005; Gomes \& Suita, 2010) are imperceptible on the topographic map (Fig. 3). The continental shelf is long, with $240 \mathrm{~km}$ of extension. The continental slope is high and steep, with $3200 \mathrm{~m}$ of relative height and $12^{\circ}$ to $15^{\circ}$ of declivity. On the other hand, the continental rise is short, low, and gentle, less than $100 \mathrm{~km}$ wide, $600 \mathrm{~m}$, high and $0.3^{\circ}$ of declivity (Fig. 4A). Such type of passive continental margin is observed characteristically in this region, and called ES-type (Motoki et al., 2012; Espírito Santo type).

On the other hand, the continental margin of the areas to south of Vitória-Trindade chain shows highly contrasted submarine morphology. The continental shelf is short, about $50 \mathrm{~km}$ wide, the continental slope is of low and relatively gentle, with $1200 \mathrm{~m}$ of relative height and $3.5^{\circ}$ of declivity. The continental rise is wide, high, and gentle, relative height, which is $150 \mathrm{~km}$ wide, $2500 \mathrm{~m}$ high, and $1.4^{\circ}$ of declivity. In addition, it is underlain by continental crust covered by sedimentary deposits. This type of passive margin is common in the offshore regions of States of Rio de Janeiro and São Paulo, and called SP-type (Motoki et al., 2012; São Paulo type).

Close to the south-eastern margin of this continental shelf, there occurs Besnard Bank with extension of $110 \times 80 \mathrm{~km}$ (Fig. 3, BSN). Between Abrolhos Continental Shelf and Besnard Bank, a rift-like deep and narrow channel is present, called Besnard Passage. This linear morphologic depression is $60 \mathrm{~km}$ long, $15 \mathrm{~km}$ wide and of $\mathrm{N}^{\circ} 5^{\circ}$ of strike. The maximum depth is $1900 \mathrm{~m}$ after GEBCO and $1700 \mathrm{~m}$ after TOPEX version 14.1. The lateral slopes of the channel are steep with average declivity of $19^{\circ}$ to $21^{\circ}$ and the channel bottom has irregular surface. Because of the peculiar morphologic characteristics, Besnard Passage is considered to be an abandoned continental rift. Besnard Bank is interpreted as a continental shelf fragment, and not, a volcanic seamount (Motoki et al., 2012).

Hotspur Seamount takes place on the abyssal plane (Fig. 3, HSP). This volcano has $70 \times 50 \mathrm{~km}$ of extension on the base, $45 \times 30 \mathrm{~km}$ on the flat-top, and $3800 \mathrm{~m}$ of relative height, being one of largest seamounts of Brazilian offshore. Minerva Seamount also is large (Fig. 3, MNR), with $150 \times 80 \mathrm{~km}$ of base, $45 \times 15 \mathrm{~km}$ of flat-top, and $3800 \mathrm{~m}$ of relative height. 


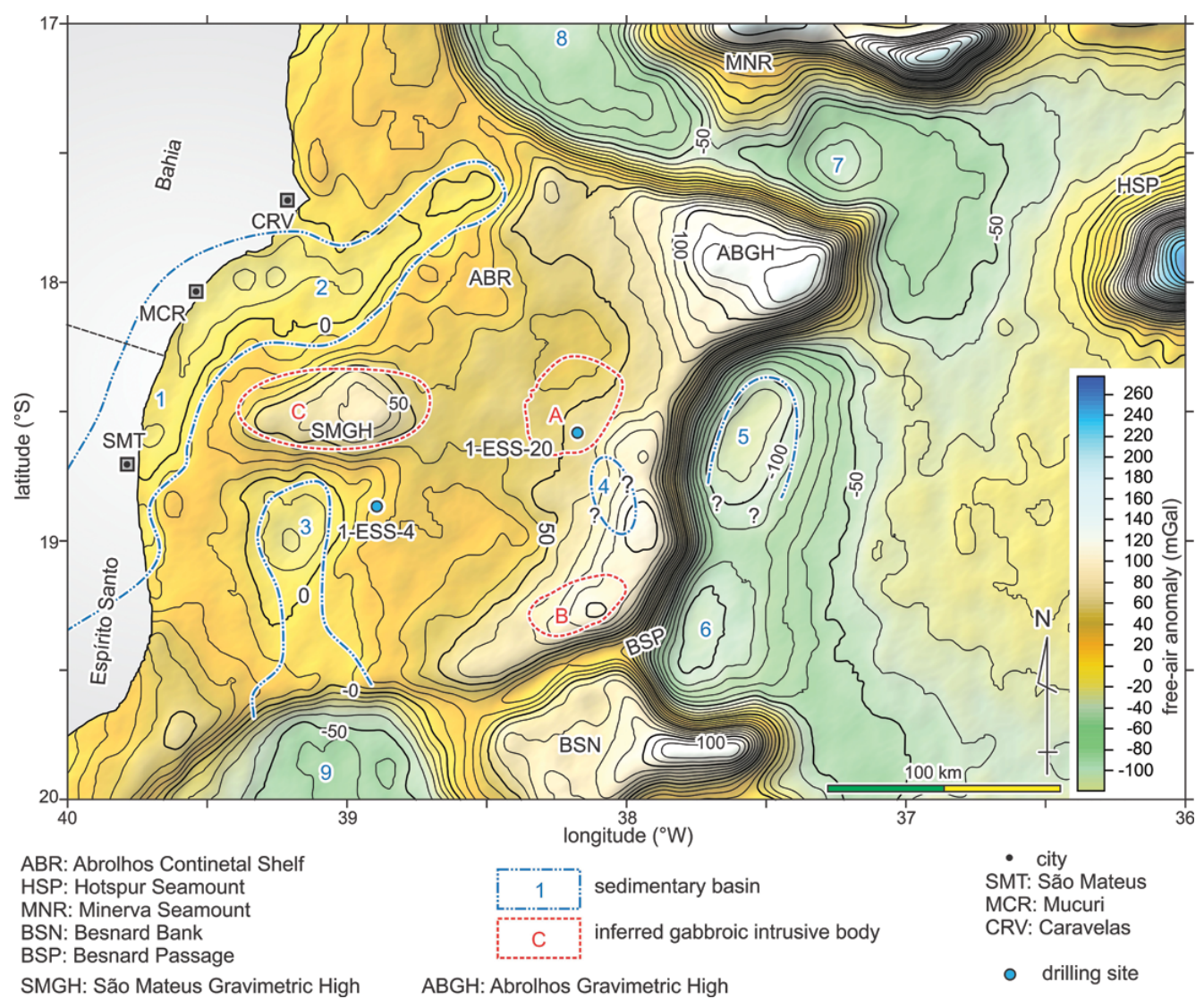

Figure $\mathbf{5}$ - Free-air anomaly map for the studied area base don Gravity Anomaly version 18. The codes, symbols, and the names of sedimentary basin are after Figure 3.

\section{FREE-AIR ANOMALY}

The Figure 5 presents free-air anomaly map for the studied area base on Gravity Anomaly version 18. The EGM2008 data shows a similar map but with lower resolution. The altitude and free-air anomaly show a positive correlation for the morphologic relieves with horizontal size minor than $50 \mathrm{~km}$, such as continental slope and seamounts. This observation indicates that the small submarine relieves are sustained mainly by mechanical strength of crust and lithospheric mantle.

Abrolhos Continental Shelf shows gradual free-air anomaly increasing from the cost to the continental shelf break with average rate of $0.5 \mathrm{mGal} / \mathrm{km}$, with total difference of $135 \mathrm{mGal}$. The freeair increase is relevant in eastern half of the continental shelf, with a rate of $1.0 \mathrm{mGal} / \mathrm{km}$. The north-eastern corner of the continental shelf has high free-air anomaly and called Abrolhos Gravimetric High (Fig. 5, ABGH). The free-air increase is observed also from Abrolhos Continental Shelf (ABR) to Besnard Bank (BSN), which is interrupted locally by Besnard Passage (BSP) in which the freeair is 40 to $60 \mathrm{mGal}$ lower than the adjacent areas.
Close to city of São Mateus (Fig. 3, SMT), a low free-air zone with NNE-SSW direction is found. The difference between the adjacent areas is about $40 \mathrm{mGal}$. In the offshore zone of Mucuri, another low Bouguer zone with NE-SW direction is present, with free-air difference of $50 \mathrm{mGal}$. These gravimetric depression zones correspond to sedimentary basins, as Espírito Santo and Mucuri basins (Fig. 5, Basins 1, 2). Considering the density of sedimentary deposits to be 2.3 (Wolfe \& McNutt, 1991), the estimated thickness of the sedimentary layers is $2.0 \mathrm{~km}$ for Espírito Santo basin and $2.5 \mathrm{~km}$ for Mucuri basin. São Mateus basin (Fig. 5, Basin 3) has local free-air anomaly 50 mGal lower than the adjacent areas. Therefore, the sedimentary deposits are estimated to be $2.5 \mathrm{~km}$ thick. The Area 4 has no local free-air depression in spite of the presence of salt domes.

São Mateus Gravimetric High (Fig. 5, SMGH) has free-air anomaly $40 \mathrm{mGal}$ higher than the adjacent areas. Attributing it to the gabbroic pluton $C$, it should be thicker than $5.0 \mathrm{~km}$. On the other hand, the plutons $A$ and $B$ show no local gravimetric relief and their size is smaller than the gravimetric sensibility limit. These plutons could be constituted by numerous intrusions 
of gabbroic dykes and sills. The basaltic bodies of Abrolhos Islands, which are interpreted as lava flows, in fact could be sills (W. Mohriak, 2011; personal communication).

Along the continental shelf break, free-air anomaly presents a drastic reduction in direction to the continental rise with very high gradient of $10 \mathrm{mGal} / \mathrm{km}$. On the foot of the continental slope, there are low free-air zones. The Basin 5 (Fig. 5), called Pedro Canário basin in this paper, has free-air anomaly $90 \mathrm{mGal}$ lower than that of the abyssal plane. The sedimentary deposit thickness is estimated to be $6.0 \mathrm{~km}$. However, the real thickness should be considerably smaller because of the gradual general increase of Bouguer anomaly from the continental slope to abyssal due to crustal thinning. The seismic section for this basin demonstrates that the sedimentary deposits are more than $4.5 \mathrm{~km}$ thick (Gladczenko et al., 1997; Fig. 4A).

In contrast with the above-mentioned submarine relieves, the abyssal plane has relatively constant free-air anomaly around $-20 \mathrm{mGal}$, without notable local variations. This observation suggests that the abyssal plane is under isostatic equilibrium.

\section{BOUGUER ANOMALY}

The Figure 6 presents Bouguer anomaly map and its E-W cross section constructed from the satellite-derived free-air and topographic data. Bouguer anomaly on Abrolhos Continental Shelf is highly coherent with free-air anomaly. The gradual increase of Bouguer anomaly from coast to the continental shelf break indicates a crustal thinning of $4.5 \mathrm{~km}$. The free-air and Bouguer anomalies on Espírito Santo, Mucuri, and São Mateus sedimentary basins (Fig. 6, Basins 1, 2, 3) have a good correlation indicating that the basement depression is sustained by strength of the underlying crust and lithospheric mantle, almost without isostatic compensation.

The supposed gabbroic intrusive body at São Mateus Gravimetric High (Fig. 6, SMGH) should have much larger horizontal extension and smaller thickness than the subvolcanic bodies of large seamounts, such as Sirius, Davis, Jaseur and VitóriaCongress (Motoki \& Motoki, 2012). In addition, the sea bottom surface at the SMGH is flat, without seamounts morphology (Fig. 3).

Sobreira \& França (2005) considered that the pluton C at the SMGH is present in lower crust where the temperature is higher than magnetic limit. Considering the Currie temperature as $580^{\circ} \mathrm{C}$, the pluton depth should be $20 \mathrm{~km}$ to $25 \mathrm{~km}$ according to average continental geothermal gradient. However, the crustal thickness estimated by Bouguer anomaly is about $18 \mathrm{~km}$, which is too small to comprise the gabbroic intrusion. An alternative idea for the solution of this controversy is local thinning of continental crust of 2.0 to $2.5 \mathrm{~km}$.
The distribution area of lavas and pyroclastic rocks on AbroIhos Continental Shelf is quite large, covering about $50 \%$ of the continental shelf (Gomes \& Suita, 2010). The thickness measured by drilling core is about $1700 \mathrm{~m}$ (Sobreira \& França, 2005). However, the volcanic deposits have no perceptible gravimetric influence due probably to high porosity and low density of these rocks.

From the continental shelf break to the abyssal plane, Bouguer anomaly demonstrates notable increase with total difference of $260 \mathrm{mGal}$, which is commonly observed in passive continental margins. The increasing rate is $1.5 \mathrm{mGal} / \mathrm{km}$ from the coast to the continental shelf break, and $0.6 \mathrm{mGal} / \mathrm{km}$ from the continental slope to the abyssal plane. The total crust thinning estimated by the Bouguer increase is about $9.0 \mathrm{~km}$.

The E-W cross section of Bouguer anomaly shows a small inflection at Pedro Canário basin (Fig. 6, Basin 5), where Bouguer anomaly is $10 \mathrm{mGal}$ lower than the adjacent area. The TOPEX data updated in 2014 indicate that the residual local Bouguer anomaly of Pedro Canário Basin (5) and Minerva Basin (7) are, respectively 40 and $30 \mathrm{mGal}$ lower than the adjacent area, which correspond respectively to 2.7 and $2.0 \mathrm{~km}$ of sedimentary deposit thickness, estimating the sediments density as $2.3 \mathrm{~g} / \mathrm{cm}^{3}$.

Besnard Passage (BSP, Fig. 5) presents free-air anomaly $40 \mathrm{mGal}$ lower than the continental shelf, but Bouguer anomaly is $80 \mathrm{mGal}$ higher. The rift-like channel is narrow, but the width of $15 \mathrm{~km}$ is enough larger than the free-air horizontal resolution, so the high Bouguer anomaly is real. If the channel morphology were sustained completely by mechanical strength of the basement, the Bouguer anomaly should be $42 \mathrm{mGal}$ lower than the continental shelf. The difference of $122 \mathrm{mGal}$ is attributed to isostatic compensation.

\section{GRAVIMETRIC INTERPRETATION DIAGRAMS}

On the diagrams of gravity anomaly $v$ s. depth, each submarine morphologic relief is projected on the specific area. These diagrams are useful for the interpretation of gravimetric data (Fig. 7) and show if the interested submarine morphologic relief is sustained by isostasy or mechanical strength of the basement. For example, the data of continental slope and seamount slope are distributed in sub-parallel to the line of no isostatic compensation, so they are sustained by mechanical strength of the basement. On the other hand, the data of abyssal plane are in sub-parallel to the complete isostatic compensation line, thus the abyssal plane is under isostatic compensation.

The authors introduce the diagrams of free-air anomaly vs. depth and free-air anomaly vs. Bouguer anomaly for geologic interpretations of the satellite-derived gravimetric data. The Figure 8 presents the gravimetric models according to each geologic structure. The models A, B, C, E, and F show the cases of which 


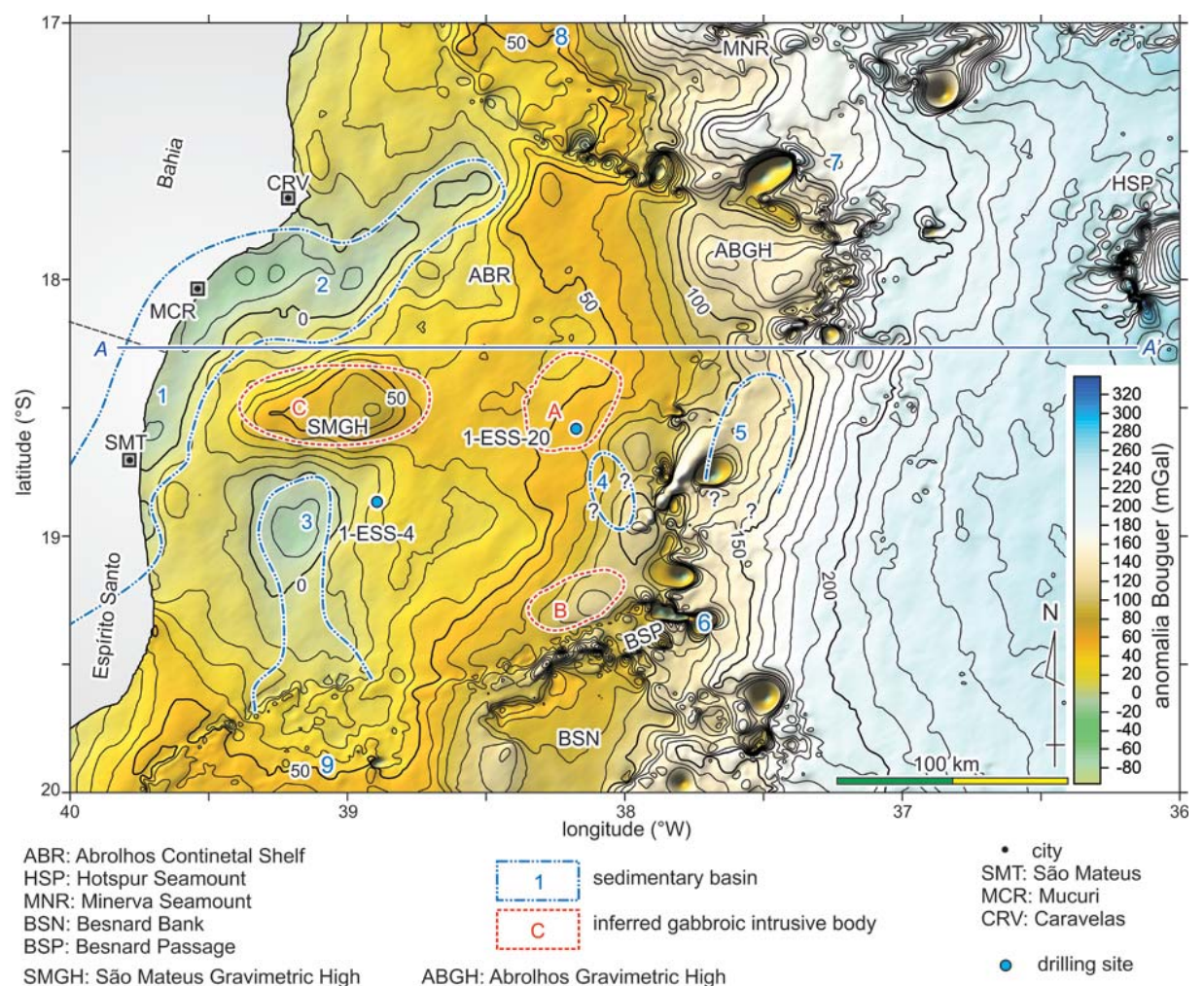

SMGH: São Mateus Gravimetric High

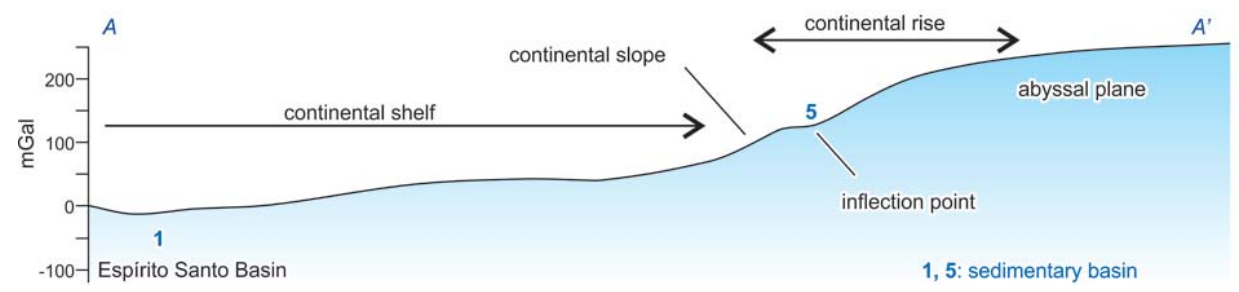

Figure 6 - Bouguer anomaly map and its E-W cross section for Abrolhos Continental Shelf and the adjacent areas, based on Gravity Anomaly version 18 and TOPEX version 14.1 data. The codes, symbols, and the names of sedimentary basin are after Figure 3.

submarine relieves are sustained by mechanical strength of the basement without isostatic compensation. The model $D$ is the opposite case, which is under complete isostatic compensation. These diagrams, namely gravimetric interpretation diagrams, suggest a suitable geologic structure according to the free-air, Bouguer, and topographic data.

In the case of simple morphologic depression without sedimentary deposits, the mass deficiency of basement depression is represented by free-air anomaly without variation of Bouguer anomaly (Fig. 8A). In the case of sedimentary basin, the mass deficiency is represented either by free-air or Bouguer anomalies. In spite of the Bouguer anomaly depression, the Mohorovicic discontinuity depth is constant (Fig. 8B). The basement depression filled partially by sedimentary deposits is the composite case (Fig. 8C). These models have no isostatic compensation effects.
On the other hand, in the case of complete isostatic compensation with Moho depth variation, the free-air anomaly is constant in spite of Bouguer anomaly variation and topographic relieves (Fig. 8D). In the case of crustal thickening (Fig. 8E) and crustal thinning (Fig. 8F) with Moho depth variation, the gravimetric patterns on these diagrams are similar to the case of sedimentary basin (Fig. 8B). However, crustal thinning causes local Bouguer high (Fig. 8F) and crustal thickening (Fig. 8E), local Bouguer low.

Among them, most common cases are: 1) Morphologic depression without isostatic compensation (Fig. 8A) as continental slope; 2) Sedimentary basin without isostatic compensation (Fig. 8B) as sedimentary basins on continental shelf; 3) Continental rift with topographic relief sustained by isostatic compensation (Fig. 8F).

The Figure 9 presents gravimetric interpretation diagrams 


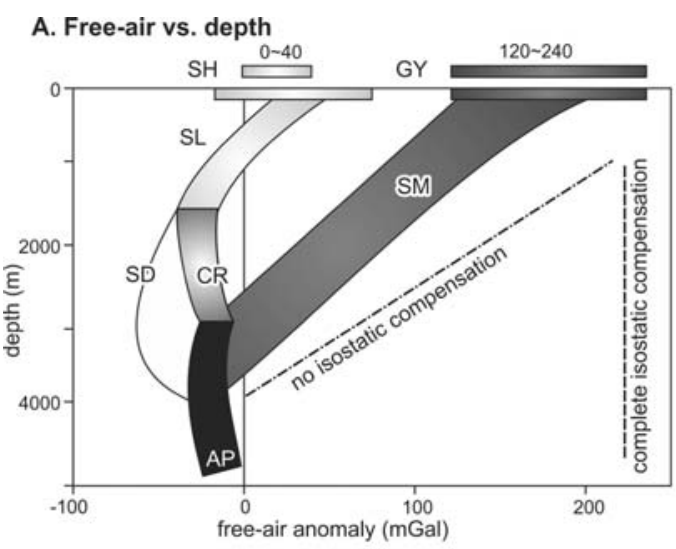

SM: volcanic seamout GY: flat-top of seamoun $\mathrm{SH}$ : continental shelf
B. Bouguer vs. depth

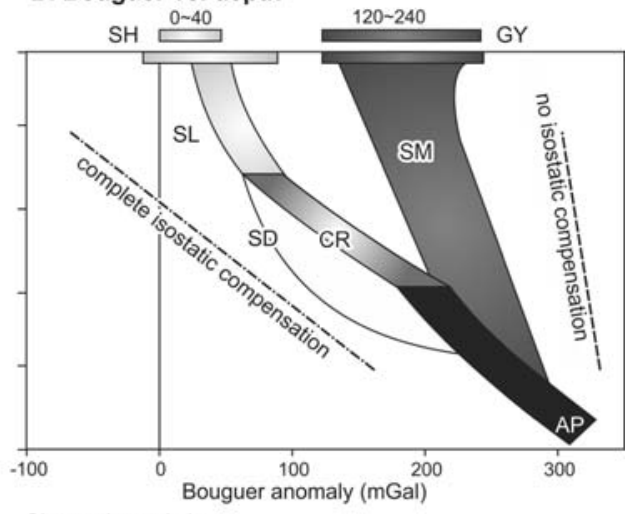

SL: continental slope

CR: continental rise

SD: CRS-type sedimentary basin

AP: abyssal plane

Figure 7 - Diagrams of gravity anomalies vs. depth for the offshore regions of States of Ceará and Rio Grande do Norte, north-eastern Brazil (Motoki \& Motoki, 2012): A) Free-air vs. depth; B) Bouguer vs. depth.

\section{A. Morphologic depression}
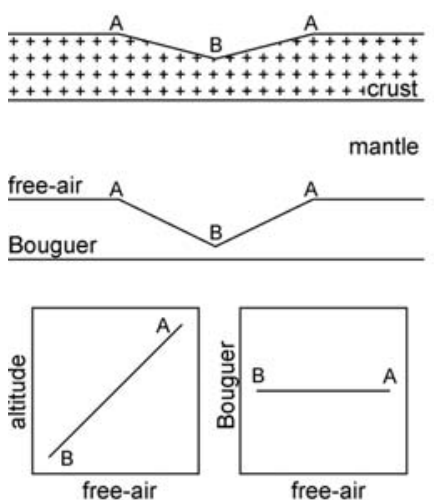

\section{Sedimentary basin with} isostatic compensation

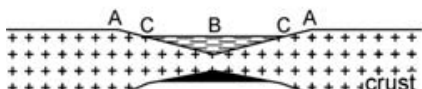
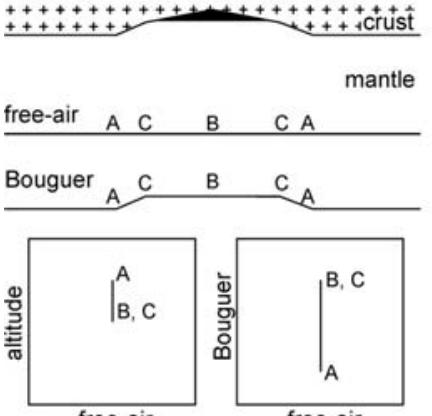

free-air
B. Sedimentary basin without isostatic compensation
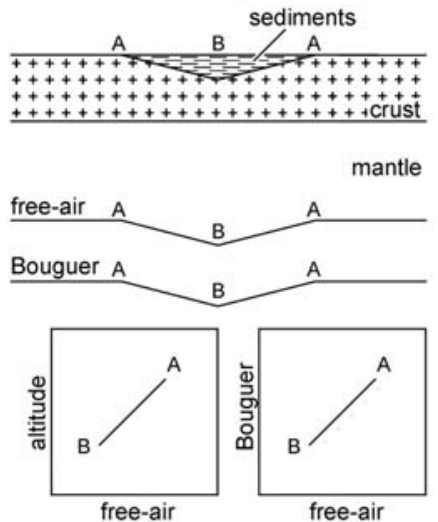

E. Crustal thickning without isostatic compensation
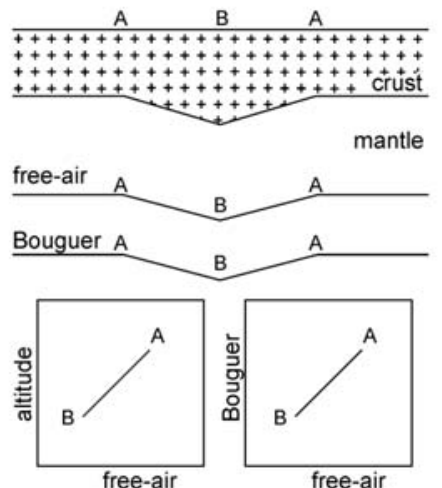

\section{Sedimentary basin with} morphologíc depression
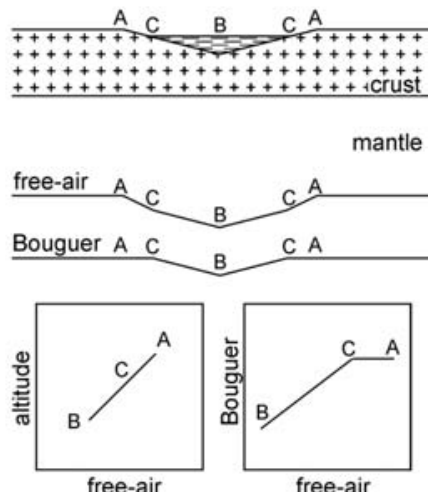

\section{F. Crustal thinning without}

$$
\text { A } \quad \text { B } \quad \text { A }
$$

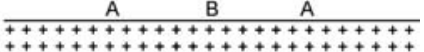

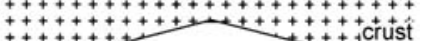
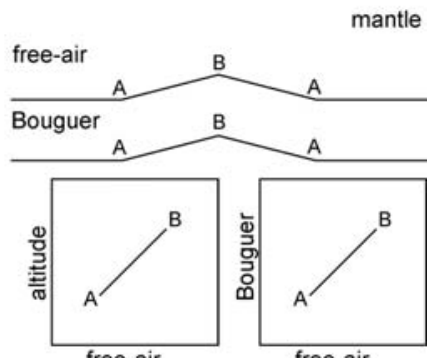

free-air

free-air

Figure 8 - Models for the interpretation of geologic structure based on satellite-derived gravimetric and topographic data: A) Simple morphologic depression; B) Sedimentary basin; C) Basement depression filled partially by sedimentary deposits; D) Continental rift; E) Crustal thickening; F) Crustal thinning. 

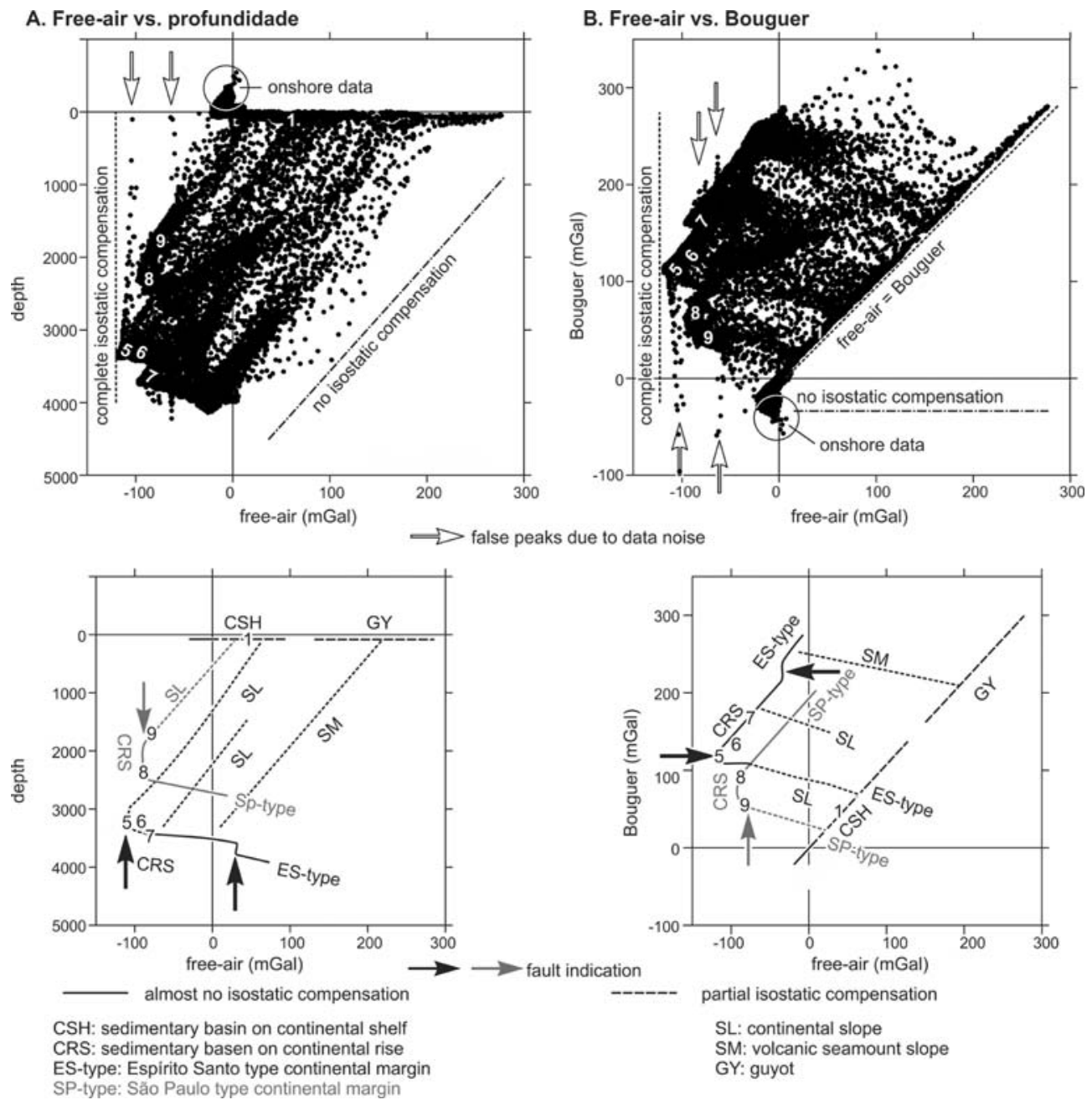

Figure 9 - Gravimetric interpretation diagrams for the studied area: A) Free-air anomaly vs. depth; B) Free-air anomaly vs. Bouguer anomaly. Open arrows point out the false topographic peaks originated from data noises. Black arrows indicate possible deep fault that continues from the surface up to the mantle. The sedimentary basins are: 1 - Espírito Santo; 5 - Pedro Canário; 6 - Besnard; 7 - Minerva; 8 - Cumuruxatiba; 9 - Linhares.

for the studied area based on TOPEX version 14.1 and Gravity Anomaly version 18. On the free-air $v$ s. Bouguer diagram (Fig. 9B), the data on the sedimentary basins without isostatic compensation lie along the line of free-air=Bouguer, according the model of Figure 8B.

The Figure 10 shows oblique view of the submarine morphologic relieves of Besnard Bank and Vitória-Congress Seamount area. The needle-like small and acute topographic peaks with extremely high slope declivity (white arrows) are considered to be false peaks originated form topographic data noises. These peaks have no association of free-air anomaly peaks (Fig. 9). Complementally, they are not observed in EGM2008 data.

Most of the data of Abrolhos Continental Shelf are projected along the line of free-air=Bouguer (Fig. 11A). The data the areas off this line are of continental slope of the Area 4 (Fig. 11B). The continental crust thinning is expressed by the arrow of the Figure $11 \mathrm{~A}$.

Espírito Santo, Mucuri, and São Mateus sedimentary basins (Fig. 6, Basins 1, 2, 3; Fig. 11, Areas 1, 2, 3) have free-air and Bouguer anomalies about 40 to $50 \mathrm{mGal}$ lower than the adjacent areas. The Bouguer depressions can be justified by the sedimentary deposits of 2.0 to $2.5 \mathrm{~km}$ of total thickness. The maximum thickness at the deposition centres could be larger than the gravimetric estimation. The basement depression of these basins is sustained by mechanical strength of the basement according to the model of the Figure 8B.

The continental slope presents an abrupt reduction of freeair anomaly with total difference of 260 mGal. The gravimetric 


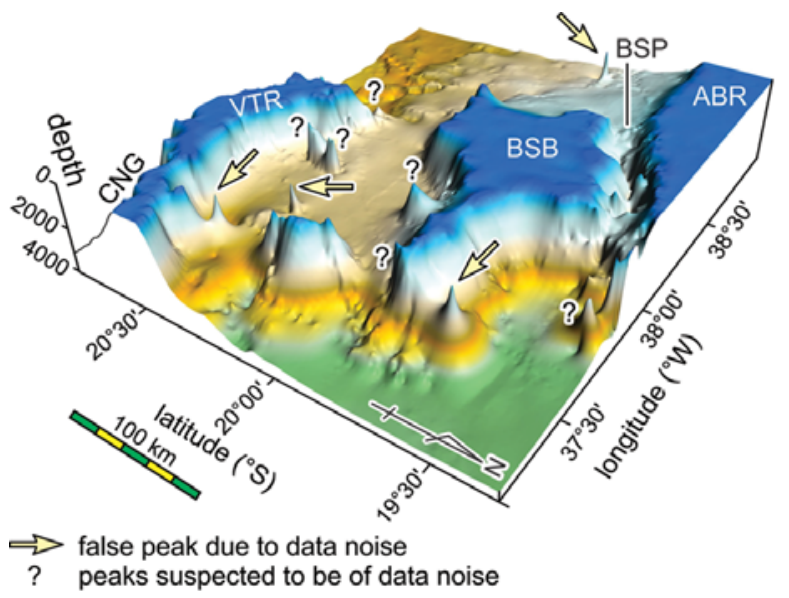

ABR: Abrolhos Continental Shelf

BSP: Besnard Passage

BSB: Besnard Bank

VTR: Vitória Seamount

CGR: Congress Bank

Figure 10 - Oblique view of submarine morphologic relieves in the area of Besnard Bank and Vitória Seamount based on TOPEX version 14.1.

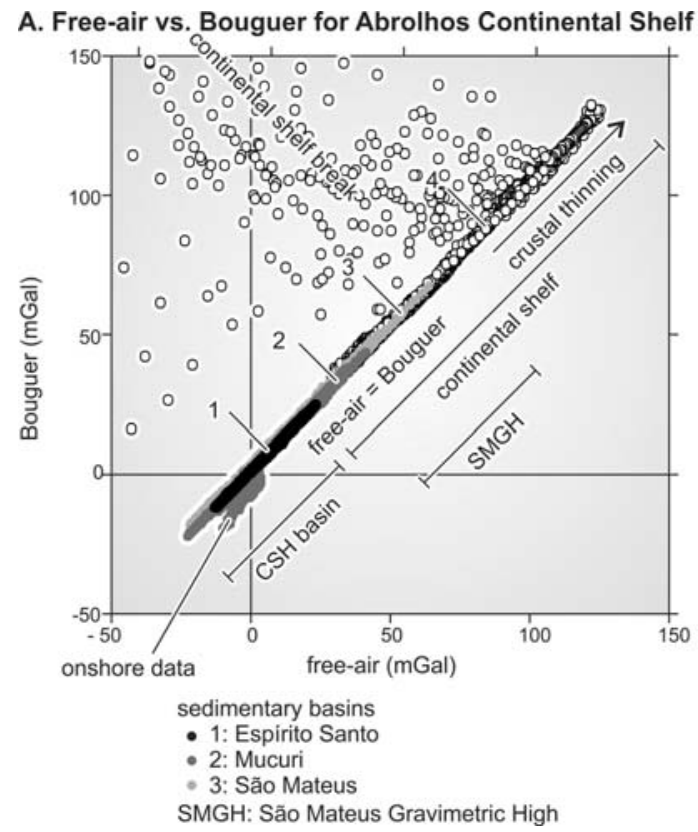

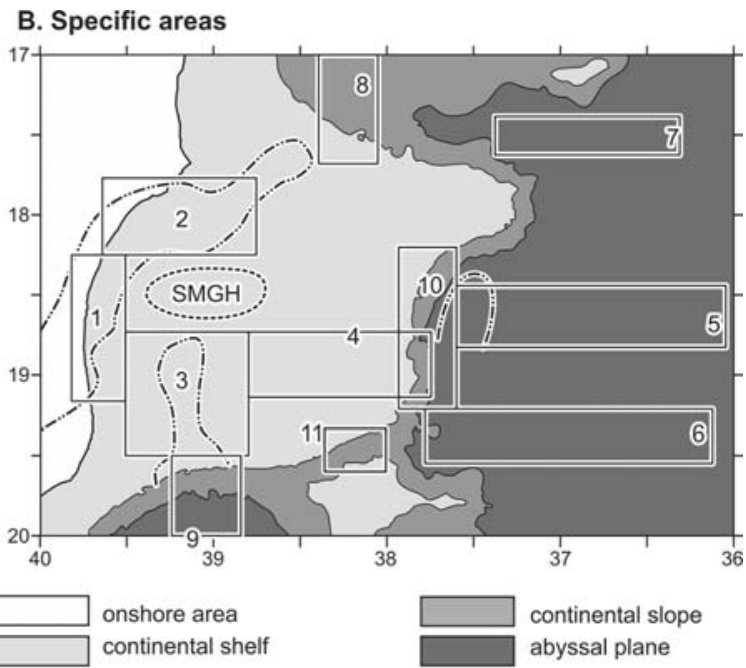

1, 2, 3: basins on continental shelf, CSH-type 4: continental shelf

5, 6, 7: bains on continental rise, CRS-type, Fig. 13

8, 9, 10: continental slope, Fig. 12

11: basins of continental rift, CRF-type, Fig. 14

Figure 11 - Gravimetric interpretation diagrams for Abrolhos Continental Shelf: A) Free-air vs. depth; B) Map indicating the specific areas for the detailed gravimetric analyses.

interpretation diagrams (Fig. 12) distinguish well ES-type passive continental margin, represented by continental slope SL10 (Fig. 11B, Area 10), and SP-type margin, by the SL8 and SL9 (Fig. 11B, Areas 8 and 9). The ES-type margin have higher freeair and Bouguer anomalies than SP-type margin.

On the diagram of free-air $v$ s. depth (Fig. 12A), the SL10 data in the depth span between sea-level and $2800 \mathrm{~m}$ are sub-parallel to the line of no isostatic compensation. Therefore, the continental slope morphology is sustained by mechanical strength of the basement without isostatic compensation, according to the model of the Figure $8 \mathrm{~A}$.

On the other hand, the data in the depth span between 2800 to $3400 \mathrm{~m}$ are sub-vertical on these diagrams. Thus, about $80 \%$ of the submarine morphology are sustained by isostatic compen- 

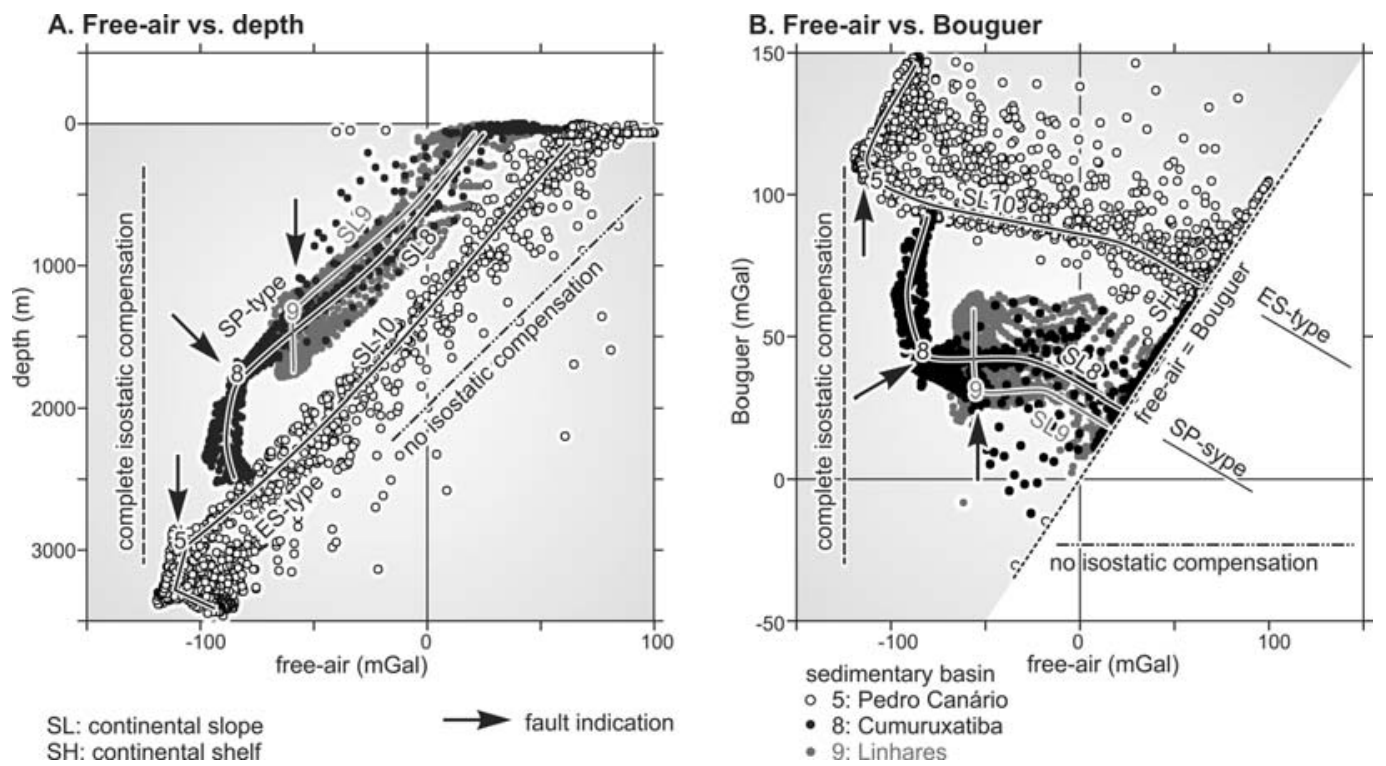

Figure 12 - Gravimetric interpretation diagram for continental slope of the studied area: A) Free-air vs. depth; B) Free-air vs. Bouguer. The continental slopes SL8, SL9, and SL10 are, respectively of the Areas 8, 9, and 10 of the Figure 11B.

sation and $20 \%$ by mechanical strength. This observation indicates that the mechanical linkage between continental slope and continental rise is loose due probably to the existence of a deep fault that continues from the Earth's surface up to the mantle (Figs. 9, 12, black arrows).

The gravimetric interpretation diagrams shows that the data of SL8 and SL9 in the depth span between sea-level and $1200 \mathrm{~m}$ (Fig. 12A) show a pattern similar to simple morphologic depression of the Figure $8 \mathrm{~A}$. It is expressed also by the sub-horizontal spans of the free-air vs. Bouguer diagram (Fig. 12B). The continental slope of these areas also is sustained by mechanical strength without isostatic compensation. The slight inflection of the SL8 and SL9 at the depth of $700 \mathrm{~m}$ (Fig. 12A) could be due to the volcanic deposits of low density which cover continental shelf. The seismic section (Fig. 4A) supports this idea.

On the other hand, the data of deeper sites of these areas are sub-parallel to the complete isostatic compensation line according to the model of the Figure $8 \mathrm{D}$. The data distribution pattern suggests the existence of deep fault between continental slope and continental rise.

The sedimentary basins of continental rise of ES-type passive continental margin, as Pedro Canário, Besnard, and Minerva basins (Fig. 3, 5, 6, Basins 5, 6, 7), exhibit free-air anomaly about $80 \mathrm{mGal}$ lower than the abyssal plane (Fig. 5). The thickness of sedimentary deposits estimated by the gravimetric low is more than $5.0 \mathrm{~km}$. Nevertheless, the Bouguer anomaly depression is small with the difference of $10 \mathrm{mGal}$ (Fig. 6). The gravimetric interpretation diagrams for these basins show a pattern similar to the model of the Figure 8B. These observations support that the mechanical linkage between these sedimentary basins and abyssal plane is strong.

The above-mentioned data indicate asymmetric structure of these basins. The continental side border is delimited by a deep fault with a strong effect of isostatic compensation and the oceanic side border is sustained by mechanical strength without isostatic compensation. The Pedro Canário basin (Basin 5) presents signals of deep fault at the eastern border (Fig. 13, grey arrow). It can be attributed also to salt domes. The seismic section (Fig. 4A) supports the salt dome model.

A sedimentary basin of the continental rift occurs at Besnard Passage. Along this rift channel, free-air anomaly is $42 \mathrm{mGal}$ lower than the adjacent areas and Bouguer anomaly is $80 \mathrm{mGal}$ higher. The measured Bouguer anomaly is $122 \mathrm{mGal}$ lower than the theoretical case of no isostatic compensation. These observations indicate that the Moho discontinuity depth along the channel is at least $6.5 \mathrm{~km}$ shallower than the adjacent continental shelf areas if the sedimentary deposits on the channel bottom are not present. However, the bottom of a narrow and deep submarine channel is generally filled by thick sedimentary deposits and the Moho depth could be shallower than the above-mentioned estimation. Supposing the sedimentary depots of $2.5 \mathrm{~km}$ of thickness, which is a probably estimation, the Moho depth should be $9 \mathrm{~km}$ shallower than the adjacent areas of continental shelf. For the definition, a ship-borne seismic profile is desired.

Lateral slopes of the channel in the depth range between sealevel and $1100 \mathrm{~m}$ are sustained by mechanical strength in 70\% 


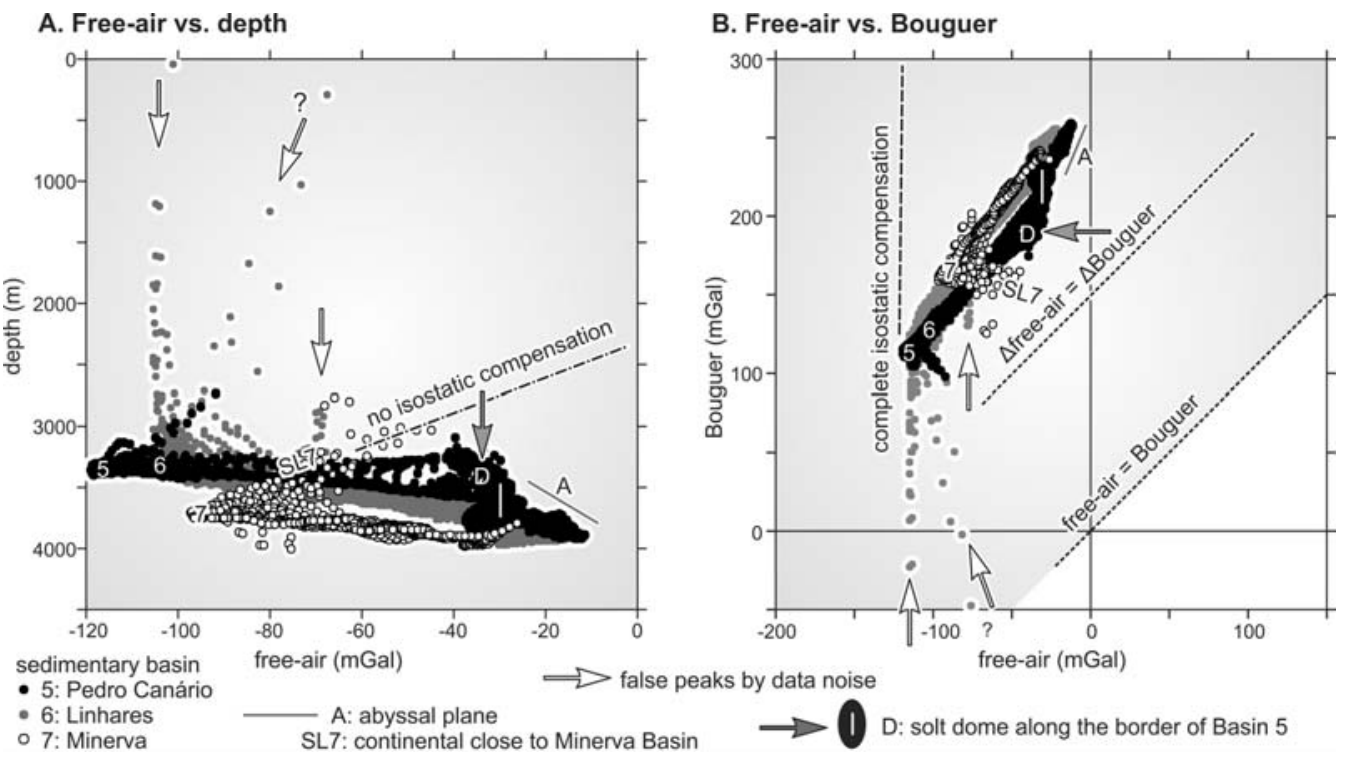

Figure 13 - Gravimetric interpretation diagrams for the sedimentary basins on the continental rise of ES-type passive margin: A) Free-air vs. depth; B) Free-air vs. Bouguer. The sedimentary basins are: 5 - Pedro Canário; 6 - Besnard; 7 - Minerva.

and by isostatic compensation in $30 \%$. The channel bottom is under complete isostatic compensation (Fig. 14). These observations suggest that the mechanical linkage between the channel slope and channel bottom is weak because of the deep normal faults of graben which continues up to the mantle (black arrow).

\section{TECTONIC GENESES OF THE SEDIMENTARY BASINS}

The previous papers proposed some types of sedimentary with different tectonic geneses (e.g. Dickinson, 1974; Klemme, 1980; Miall, 1984; Ingersoll, 1988; Martins-Neto, 2006). The satellitederived gravimetric data for the studied area indicate three types of sedimentary basins with different crustal structure and tectonic genesis (Fig. 15):

1) Basins on continental shelf originated from upper crust fracturing;

2) Basins on continental rise at continent-ocean transition;

3) Continental rift basin originated from mantle tectonism and its influence to the Earth's surface.

The sedimentary basins on continental shelf (Fig. 15, CSHtype) are $30 \mathrm{~km}$ to $50 \mathrm{~km}$ wide and $80 \mathrm{~km}$ to $120 \mathrm{~km}$ long with symmetric structure, such as Espírito Santo basin. The free-air and Bouguer anomaly show similar and coherent negative variations which are 40 to 50 mGal lower than the adjacent areas (Fig. 11A). The basement depression is sustained by mechanical strength of continental crust without isostatic compensation and Moho depth variation (Fig. 8B). The normal faults of the graben are limited within brittle upper crust without continuation to the mantle. The directions of basin border faults can be influenced by the fracture systems in the basement. However, the fault movement is originated fundamentally from the extensional lithospheric tectonism related to the Pangea break-up and Atlantic Ocean opening of the Cretaceous to Early Cenozoic (Aires et al., 2012).

The basins on continental rise (Fig. 15, CRS-type) are characterised by thick sedimentary deposits, such Pedro Canário basin. This sedimentary basin has low local Bouguer residual anomaly with difference of $40 \mathrm{mGal}$, corresponding to sedimentary deposits of $2.7 \mathrm{~km}$ thickness. The gravimetric interpretation diagrams suggest that the continental side border of the basins is under isostatic compensation and the oceanic side border is sustained by basement strength. This asymmetric structure is due to the deep normal fault between continental slope and continental rise.

The continental rift basin (Fig. 15, CRF-type) is originated from extensional tectonism of lithospheric mantle. The fault movement reached Earth's surface penetrating the crust. Moho discontinuity along Bernard Passage is at least $6.5 \mathrm{~km}$ shallower than the adjacent areas. The gravimetric interpretation diagrams suggest that the rift channel bottom is under complete isostatic compensation.

São Mateus Gravimetric High (SMGH) has coherent positive variation of free-air and Bouguer anomalies. Considering the crust thickness and geothermal gradient, gabbroic intrusion 
A. Free-air vs. depth

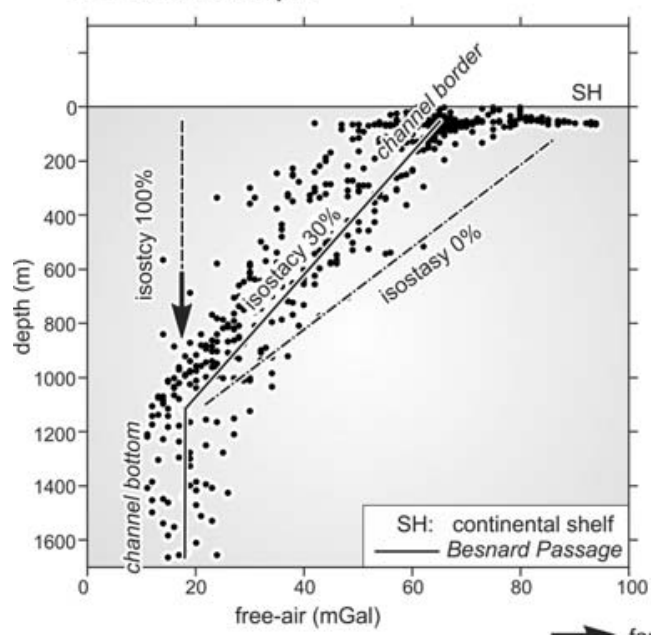

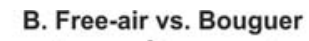

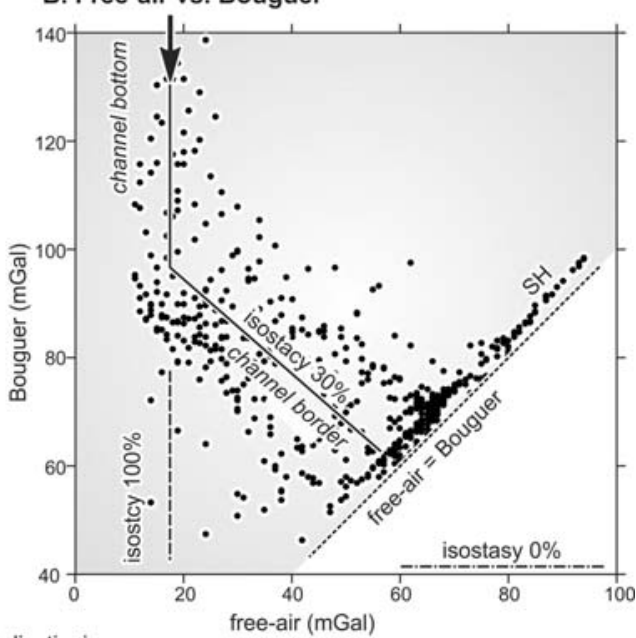

Figure 14 - Gravimetric interpretation diagram for the area of Besnard Passage: A) Free-air vs. depth; B) Free-air vs. Bouguer.

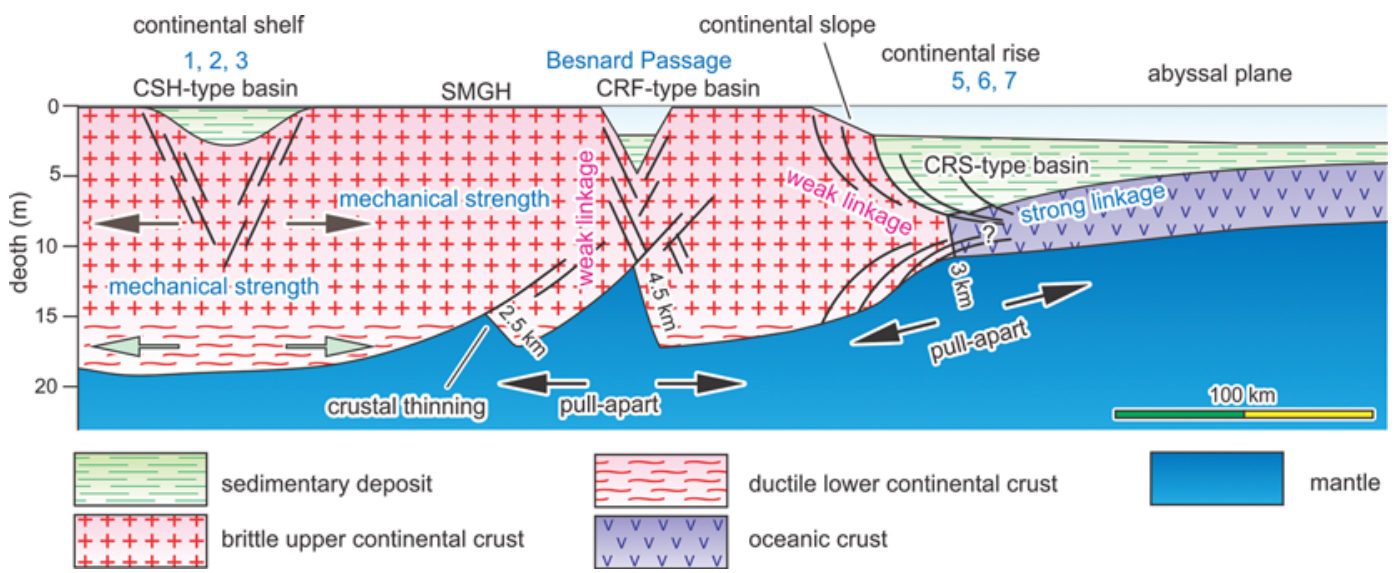

Figure 15 - Schematic model for the three types of sedimentary basins: 1) Basins on continental shelf, CSH-type; 2) Basins on continental rise, CRS-type; 3) Continental rift basin, CRF-type. The sedimentary basin names are: 1 - Espírito Santo; 2 - Mucuri; 3 - São Mateus; 5 - Pedro Canário; 6 - Besnard;

model is unfeasible. The high gravity anomaly can be attributed also to local crustal thinning according to the model of Figure 8F. On the contrary of CRF-type basins, the relief of the crust-mantle boundary is sustained by mechanical strength of upper crust. The tectonism is limited within lower crust without influence to upper crust and Earth's surface.

The above-mentioned models explain rationally all of the observations based on the satellite-derived gravimetry and the previous ship-borne data, without notable controversies. However, these considerations are a possible solution, and not, the unique and absolute one. Gravimetric anomalies can be attributed either to geologic structure, as crustal thickness, or to constituent material density, as sedimentary deposits. Hence other types of complementally data are desired.

\section{CONCLUSION}

The satellite-derived gravimetry for Abrolhos Continental Shelf and the adjacent areas and their analyses with the help of gravimetric interpretation diagrams lead the authors to the following conclusions:

1. The free-air and Bouguer anomalies on the continental shelf present a gradual increase from the cost to the continental shelf break. The total difference of $135 \mathrm{mGal}$ corresponds to continental a crust thinning of $4.5 \mathrm{~km}$. The gravity anomalies suggest that Besnard Bank is a continental shelf fragment, and not a volcanic seamount;

2. The Bouguer anomaly presents the increase beyond continental shelf break, from the coast to the abyssal plane. The 
total difference of $260 \mathrm{mGal}$ corresponds to the continental crust thinning of about $9.0 \mathrm{~km}$;

3. In the studied area, two different types of continental margin are observed: 1) ES-type with high continental slope, low and narrow continental rise, and high free-air and Bouguer anomalies; 2) SP-type with low continental slope, high and wide continental rise, and low gravity anomalies;

4. There are three types of sedimentary basins with different geologic structure and tectonic genesis: 1) Basins on continental shelf, CSH-type; 2) Basin on continental rise, CRS-type; 3) Continental rift basin, CRF-type;

5. The CSH-type, as Espírito Santo and Mucuri basins, has highly coherent free-air and Bouguer anomaly depressions which are 40 to $50 \mathrm{mGal}$ lower than the adjacent areas. The sedimentary deposits are estimated to be $2.0 \mathrm{~km}$ to $2.5 \mathrm{~km}$ thick. In spite of the Bouguer variation, the Moho depth is constant. The basement depression is sustained by mechanical strength without isostatic compensation. These basins are originated from normal faults within continental upper crust;

6. The CRS-type, as Pedro Canário and Minerva basins, show low local residual Bouguer anomaly with a difference of $40 \mathrm{mGal}$. The sedimentary deposits are more than $2.7 \mathrm{~km}$ thick. This type of basins has asymmetric structure. The continental side border is under isostatic compensation because of the deep normal fault between the continental slope and continental rise. The oceanic side border is of low angle and sustained by mechanical strength of the basement;

7. The CRF-type, Besnard Passage, is continental rift basin originated from mantle tectonism with crustal influence. The rift bottom is under complete isostatic compensation. The normal faults of the graben penetrate the entire crust and continue up to the mantle. The Moho depth along the rift is at least $6.5 \mathrm{~km}$ shallower than the adjacent areas;

8. São Mateus Gravimetric High (SMGH) is attributed to local crustal thinning originated from the relief of the crustmantle boundary. It is sustained by mechanical strength of upper crust and the tectonism is limited in lower crust.

\section{ACKNOWLEDGEMENT}

Processing of the satellite-derived data for this article has been performed with the help of high duty, high speed, and high graphic resolution equipments of the informatics which were obtained by the financial support of FAPERJ (Scientific Support Founda- tion of State of Rio de Janeiro) and Petrobras (Brazilian National Petroleum Company). The authors are grateful to these institutions.

\section{REFERENCES}

AIRES JR, MOTOKI A, MOTOKI KF, MOTOKI DF \& RODRIGUES JG. 2012. Geomorphological analyses of the Teresópolis Plateau and Serra do Mar Cliff, State of Rio de Janeiro, Brazil with the help of summit level technique and ASTER GDEM, and its relation to the Cenozoic tectonism. Anuário do Instituto de Geociências da Universidade Federal do Rio de Janeiro, 35(2): 105-123.

CAMPOS TFC, BEZERRA FHR, SRIVASTAVA NK, VIEIRA MM \& VITAFINZI C. 2010. Holocene tectonic uplift of the St Peter and St Paul Rocks (Equatorial Atlantic) consistent with emplacement by extrusion. Marine Geology, 271: 177-186.

DICKINSON WR. 1974. Plate tectonics and sedimentation. In: DICKINSON WR (Ed.). Tectonics and Sedimentation. SEPM, Special Publication, 22: $1-27$.

DOUGLAS BC \& GOAD CC. 1978. The role of orbit determination in satellite altimeter data analysis. Boundary-Layer Meteorology, 13(1-4): 245-251.

FRANÇA RL, DEL REY AC, TAGLIARI CV, BRANDÃO JR \& FONTANELLI PR. 2007a. Bacia do Espírito Santo. Boletim de Geociências da Petrobras, 15(2): 501-509.

FRANÇA RL, DEL REY AC, TAGLIARI CV, BRANDÃO JR \& FONTANELLI PR. 2007b. Bacia de Mucuri. Boletim de Geociências da Petrobras, 15(2): 493-499.

GLADCZENKO TP, HINZ K, ELDHOLM O, MEYER H, NEBEN S \& SKOGSEID J. 1997. South Atlantic volcanic margins. Journal of the Geological Society, 154: 465-470.

GOMES NS \& SUITA MTF. 2010. Ocorrência de vulcanismo bimodal de idade terciária. Boletim de Geociências da Petrobras, 18(2): 232-248.

GOOSSENS S, MATSUMOTO K, LIU Q, KIKUCHI F, SATO K, HANADA H, ISHIHARA Y, NODA H, KAWANO N, NAMIKI N, IWATA T, LEMOINE FG, ROWLANDS DD, HARADA Y \& CHEN M. 2011. Lunar gravity field determination using SELENE same-beam differential VLBI tracking data. Journal of Geodesy, 85(4): 205-228.

INGERSOLL RV. 1988. Tectonics of sedimentary basins. Geological Society of America Bulletin, 100: 1704-1719.

KAULA WM. 1987. Satellite measurement of the Earth's gravity field. Methods of Experimental Physics, 24B: 163-187.

KLEMME HD. 1980. Petroleum basins-classifications and characteristics. J. Petrol. Geol., 3: 187-207.

LAMBECK K \& COLEMANR. 1983. The Earth's shape and gravity field: a report of progress from 1958 to 1982 . Geophysical Journal International, 74(1): 25-54.

LORELL J. 1970. Lunar orbiter gravity analysis. Moon, Earth, and Planets, 1(2): 190-231. 
MARTINS-NETO MA. 2006. Classificação de bacias sedimentares: uma revisão comentada. Revista Brasileira de Geociências, 36(1): 165-176.

MIALL AD. 1984. Principles of Sedimentary Basin Analysis. SpringerVerlag, New York, 490 pp.

MOHRIAK WU. 2003. Bacias Sedimentares da Margem Continental Brasileira. In: BIZZI LA, SCHOBBENHAUS C, VIDOTTI RM \& GONÇALVES JH (Eds.). Geologia, Tectônica e Recursos Minerais do Brasil. Brasília, Brazil. Cap. III, p. 87-165.

MOTOKI A \& MOTOKI KF. 2012. Satellite gravimetry for the Fernando de Noronha Chain, Northeast Brazil, and its bearing on the volcanic seamount structure. In: Simpósio Brasileiro de Geofísica, 5., Proceedings... Salvador, Brazil: SBGf, CD-ROM, 6 pp.

MOTOKI A, NOVAIS LCC, SICHEL SE, NEVES JL \& AIRES JR. 2007. Felsic pyroclastic rock originated from subaqueous eruption in the Espirito Santo sedimentary basin: an association with the tectonicsedimentary model. Geociências, 26(2): 151-160.

MOTOKI A, SICHEL SE, CAMPOS TFC, SRIVASTAVANK \& SOARES RS. 2009. Present-day uplift rate of the Saint Peter and Saint Paul Islets, Equatorial Atlantic Ocean. REM-Revista Escola de Minas, 62(3): 331342.

MOTOKI A, MOTOKI KF \& MELO DP. 2012. Submarine morphology characterization of the Vitória-Trindade Chain and the adjacentareas, State of Espírito Santo, Brazil, based on the predicted bathymetry of the TOPO version 14.1. Revista Brasileira de Geomorfologia, 13(2): 151-170.

MOTOKI KF, MOTOKI A \& SICHEL SE. 2014. Gravimetric structure for the abyssal mantle exhumation massif of Saint Peter and Saint Paul Peridotite Ridge, Equatorial Atlantic Ocean, and its relation to the active uplift driving force. Anais da Academia Brasileira de Ciências, 86(2): $571-588$.

MULLER PM \& SJOGREN WL. 1968. Mascons: Lunar Mass Concentrations. Science, 161(3842): 680-684.

NOVAIS LCC, TEIXEIRA LB, NEVES MT, RODARTE JBM, ALMEIDA JCH \& VALERIANO CM. 2003. Novas ocorrências de diques de diabásio na faixa Colatina - ES: estruturas rúpteis associadas e implicações tectônicas para as bacias de Campos e do Espírito Santo. Boletim de Geociências da Petrobras, 12(1): 191-194.

NOVAIS LCC, NEVES MT, COSTA RC, LOWSBY MG, SUGUIO AH, OLIVEIRA ML \& ANJOS KM. 2006. Modelo estrutural dos campos petrolíferos com alto grau de explotação, na porção terrestre da Bacia do Espírito Santo. In: Congresso Brasileiro de Geologia, 43., Proceedings... Aracaju, Brazil: SBG, CD-ROM.

NOVAIS LCC, ZELENKA T, SZATMARI P, MOTOKI A, AIRES JR \& TAGLIARI CV. 2007. Ocorrência de rochas vulcânicas ignimbríticas na porção norte da Bacia do Espírito Santo: evolução do modelo tectonosedimentar. Boletim de Geociências da Petrobras, 16(1): 139-156.
REIGBER C, BALMINO G, SCHWINTZER P, BIANCALE R, BODE A, LEMOINE JM, KÖNIG R, LOYER S, NEUMAYER $H$, MARTY JC, BARTHELMES F, PEROSANZ F \& ZHU SY. 2002. A high-quality global gravity field model from CHAMP GPS tracking data and accelerometry (EIGEN-1S). Geophysical Research Letters, 29(14): 371-374.

REMUS MVD, SOUZA RS, CUPERTINHO JA, ROS LF, DANI ND \& VIGNOL-LALAGE MA. 2008. Proveniência sedimentar: métodos e técnicas analíticas aplicadas. Revista Brasileira de Geociências, 38(2): 166-185.

REUBELT T, AUSTEN G \& GRAFAREND EW. 2003. Harmonic analysis of the Earth's gravitational field by means of semi-continuous ephemerides of a low Earth orbiting GPS-tracked satellite. Case study: CHAMP. 77, Journal of Geodesy, 5(6): 257-278.

RUMMEL R. 2005. Gravity and topography of Moon and planets. Earth, Moon, and Planets, 94: 103-111.

SANDWELL DT \& SMITH WH. 2009. Global marine gravity from retracked Geosat and ERS-1 altimetry: Ridge segmentation versus spreading rate. Journal of Geophysical Research, 114: B01411.

SICHEL SE, ESPERANÇA S, MOTOKI A, MAIA M, HORAN MF, SZATMARI P, ALVES EC \& MELLO SLM. 2008. Geophysical and geochemical evidence for cold upper mantle beneath the Equatorial Atlantic Ocean. Brazilian Journal of Geophysics, 26(1): 69-86.

SICHEL SE, MOTOKI A, CAMPOS TFC, ANGEL-AMAYA J, VARGAS T, MAIA M, BAPTISTA NETO JA, KOGA MS, MOTOKI KF, SIMÕES LSA, GORINI MA \& SZATMARI P. 2011. Origem e evolução das rochas mantélicas da Cadeia Peridotítica de São Pedro e São Paulo, Oceano Atlântico Equatorial. Boletim de Geociências da Petrobras, 20(1-2): 97-128.

SMITH WH \& SANDWELL DT. 1997. Global sea floor topography from satellite altimetry and ship depth soundings. Science Magazine, 277(5334): 1957-1962.

SOBREIRA JFF \& FRANÇA RL. 2005. Um modelo tectonomagmático para a região do complexo vulcânico de Abrolhos. Boletim de Geociências da Petrobras, 14: 143-147.

VIEIRA RAB. 1998. Análise estratigráfica e evolução peleogeográfica da seção neoaptiana na porção sul da Plataforma de São Mateus, Bacia do Espírito Santo, Brasil. Master dissertation, Universidade Federal do Rio Grande do Sul, Porto Alegre, Brazil, 158 pp.

WOLFE CJ \& McNUTT MK. 1991. Compensation of Cretaceous seamounts of the Darwin Rise, northwest Pacific Ocean. Journal of Geophysical Research, 96: 2363-2374.

ZUBER MT, SMITH DE, LEMOINE FG \& NEUMANN GA. 1994. The Shape and Internal Structure of the Moon from the Clementine Mission. Science, 266(5192): 1839-1843. 


\section{NOTES ABOUT THE AUTHORS}

Akihisa Motoki (in memoriam ). Bachelor in Science at Faculty of Science, Kobe University, Japan, in 1977. Master in Science at Graduated School of Kobe University, Japan, in 1979. Doctor in Geology at Instituto de Geociências, Universidade de São Paulo (USP), Brazil, in 1986. Associated professor of Department of Mineralogy and Petrology, Universidade do Estado do Rio de Janeiro (UERJ), Brazil. Specialised in satellite-derived gravimetry, geomorphology, and igneous petrology.

Luiz Carlos Chaves Novais. Bachelor in Geology at Universidade Federal do Rio de Janeiro (UFRJ). Master in Geology at Faculty of Geology, Universidade do Estado do Rio de Janeiro (UERJ) in 2005. Present position at Unidade de Negócio de Exploração e Produção of Espírito Santo, Reserver Gerency of Petrobras at Vitória, Brazil.

Kenji Freire Motoki. Bachelor in Geophysics at Universidade Federal Fluminense (UFF) in 2013. Graduates school student of Department of Geology, Universidade Federal Fluminense (UFF), Niterói, Brazil. Specialised in satellite-derived gravimetry and ocean geophysics.

Leonardo Costa de Oliveira. Bachelor in Geology at Universidade Federal Rural do Rio de Janeiro (UFRRJ). Master in Geology at Faculty of Geology, Universidade do Estado do Rio de Janeiro (UERJ) in 2009. Present position at the Headquarter Office of Petrobras. Specialised in stratigraphy, geotectonics, and sedimentary petrology, at Rio de Janeiro, Brazil.

Ricardo de Souza Fasolo. Undergraduated student of Universidade Federal do Espírito Santo (UFES), São Mateus (CEUNES), Brazil. Specialised in geophysics.

Adrienne Brito Lima. Undergraduated student of Universidade Federal do Espírito Santo (UFES), São Mateus (CEUNES), Brazil. Specialised in geophysics. 